\title{
Penerapan Metode Bermain Peran (Role Playing) dalam Mengembangkan Kognitif Anak Usia 5-6 Tahun
}

\author{
Wardah Anggraini ${ }^{1}$, Anggi Darma Putri ${ }^{2}$
}

\begin{abstract}
This study aims to find out how the application of the role playing method in developing cognitive skills of children aged 5-6 years. The problem in this study is the low cognitive development of children aged 5-6 years and the hope that the role playing method still uses limited media in RA Az-Zahra Natar, South Lampung. The method used in this research is a descriptive qualitative method that describes how the role playing method is used at RA Az-Zahra Natar, South Lampung. Data collection techniques used were observation, interviews and documentation. Analysis of the data used is the analysis of miles and huberman model data, namely data reduction, data collection and conclusion drawing. Based on data collection and analysis conducted there are several findings of research results about playing a role in developing cognitive children aged 5-6 years. The results of this research are the application of the steps used in role playing, i.eWarming up (warming up), participants (choosing players), setting the stage, observers (preparing observers), holding (ensuring roles), discussion and evaluation, reusing (playing back roles), second discussion and evaluation, various conclusions and experiences.
\end{abstract}

Keywords: Role Playing Method, Cognitive Development, Children 5-6 years old

Abstrak: Tujuan dalam penelitian ini adalah dapat mengetahui penerapan metode bermain peran dalam mengembangkan kognitif anak usia 5-6 tahun. Permasalahan dalam penelitian ini adalah rendahnya perkembangan kognitif anak usia 5-6 tahun dan penarapan metode bermain peran masih menggunakan media yang terbatas di RA Az-Zahra Natar Lampung Selatan. Metode yang digunakan dalam penelitian merupakan metode deskriptif kualitatif yaitu mendeskripsikan bagaimana metode bermain peran digunakan di RA Az-Zahra Natar Lampung Selatan. Teknik pengumpulan data yang digunakan adalah observasi, wawancara dan dokumentasi. Analisis data yang digunakan adalah analisis data model miles and huberman yaitu reduksi data, penyejian data dn penarikan kesimpulan. Berdasarkan pengumpulan data dan analisis yang dilakukan terdapat beberapa temuan hasil penelitian tentang bermain peran dalam mengembangkan kognitif anak usia 5-6 tahun. Hasil dari penelitian tersebut adalah penerapan langkah-langkah yang digunakan dalam role playing yaitu Warming up (pemanasan), partisipan (memilih pemain), menata panggung, 
observer (menyiapkan pengamat), menggung ( memaminkan peran), diskusi dan evaluasi, menggung ulang (memainkan peran kembali), diskusi dan evaluasi kedua, berbagai kesimpulan dan pengalaman.

Kata Kunci: Metode Bermain Peran, Perkembangan Kognitif, Anak Usia 56 tahun

\section{PENDAHULUAN}

Pendidikan adalah bagian terpenting dalam kehidupan manusia, karena pendidikan merupakanlah yang akan membedakan antara manusia dengan makhluk lainnya. Namun, bukan berarti makhluk hidup lainnya tidak belajar. Contohnya hewan, hewan belajar tetapi lebih di tentukan oleh instingnya. Seangkan manusia belajar adalah rangkaian proses kegiatan menuju pendewasaan yang bertujuan mencapai kehidupan yang berarti dan bermakna.(Anwar, 2014, p. 73). Pendidikan anak usia dini adalah suatu proses pendidikan yang diberikan kepada anak yang berusia 0-6 tahun untuk memberikan rangsangan agar pertumbuhan dan perkembangannya terjadi secara optimal dan siap melanjutkan pendidikan dasar. Anak usia dini 06 tahun berada pada masa keemasan (golden age) yang perkembangan dan pertumbuhan anak usia dini terjadi sangat cepat dan pesat. Ada beberapa pendapat ahli yang mengungkapkan bahwa bayi lahir seperti tabularasa atau kertas kosong. oleh karena itu sebagai orang dewasa di sekitar anak usia dini haruslah memberikan pengalaman dan proses belajar yang baik, karena anak-anak belaar dari lingkungan sekitar.(Wiwien, 2008, p. 3).

Menurut Dinar Wiwien bahwa anak yang berada pada usia dini memiliki pertumbuhan dan perkembangan yang pesat dibandingkan usia-usia selanjutnya karena perkembangan kecerdasan dalam ranah kognitif sangat luar biasa. Dalam usia tersebut anak memiliki fase keunikan tersendiri yaitu ingin mengetahui banyak hal, sehingga pengetahuan yang di dapat anak menjadi bekal kehidupannya kelak. Proses perubahan ini terjadi secara terus menerus dan berkesinambungan dan berlangsung seumur hidup.(Wiwien, 2008, p. 11). Novan Ardy Wiyani berpendapat bahwa saat ini PAUD sedang menjadi fokus perbincangan pemerintah, dan masyrakat sekitar. Ketertarikan masyarakat untuk dapat menyekolahkan anaknya di lembaga PAUD terjadi lantaran masyarakat sudah mengetahui betapa pentingnya usia dini di stimulus agar perkembangan dan pertumbuhan terjadi secara optimal. Keterkaitan inilah yang menjadikan lembaga-lembaga PAUD tumbuh dan berkembang secara pesat seperti jamur yang tumbuh dimusim penghujan karena banyaknya orangtua yang menyekolahkan anaknya di lembaga-lembaga PAUD.(Wiyani, 2014, p. 1)

Ada beberapa aspek yang sangat penting untuk diteliti dan dikaji lebih dalam yaitu kognitif, sosial emosional, moral dan agama, fisik motorik, bahasa dan seni. Ke enam aspek itulah yang akan menjadikan pertumbuhan dan perkembangan anak terjadi secara optimal jika distimulus dengan tepat. Namun yang menjadi fokus dalam penelitian ini adalah perkembangan kognitif.

Daniel mengemukakan bahwa perkembangan kognitif adalah suatu susunan yang akan menggambarkan kemampuan mental seseorang yang meliputi kemampuan memecahkan masalah, pemikiran yang abstrak dan belajar dari sebuah pengalaman. (Eleanor Sautelle, Terry Bowles, John Hattie, 2015, p. 57). Sejalan dengan pendapat salmiati yang mengatakan bahwa pekembangan kognitif adalah kemmapuan seorang 
untuk berfikir, dalam memahami masalah, mengingat segala yang ada di sekitarnya dengan melibatkan proses mental meliputi, penyerapan, pengorganissian dan mencerna segala bentuk ifomasi yang di dapat. (Salmiati, Nurbaity, 2016, p. 65).

Hasil dari pra survey yang dilakukan pada anak usia 5-6 tahun di RA Az-Zahra Natar Lampung Selatan bahwa diperoleh gambaran bahwa dalam perkembangan kognitif belum berkembang secara optimal. Hal tersebut dapat dilihat dari hasil pra survey yang dilakukan pada anak kelompok B1 RAAz-Zahra Natar Lampung. Hal tersebut sejala dengan prolehan data yang di dapat yaitu terdapat 2 anak atau $10 \%$ yang dalam perkembangan kognitif berada pada pencapaian belum berkembang, kemudian terdapat 13 anak atau $65 \%$ berada pada pencapaian berkemang sesuai harapan dan $25 \&$ atau 5 orang anak pada pencapaian berkembang sangat baik.

Hasil pr survey tersebut disimpulkan bahwa perkembangan kogniti di RA AzZahra Natar Lampung Selatan masih harus ditingkatkan. Hal tersebut dikaenakan terbatasnya media yang digunakan dlam kegiatan pembeajaran. Hal tersebut diperkuat oleh slah satu guru, beliau mengatakan bahwa alat permainan edukatif yang digunakan dalam kegiatan sangat minim dan terbatas sehingga guru hanya memanfaatkan media yang ada di sekolah.

Penelitian sebelumnya yang dilakukan oleh Diah Maulida bahwa dalam aspek perkembangan kognitif anak belum dimiliki dengan baik, karena pada taman kanakkanak tersebut masih diterapkannya konsep dan hafalan, hal tersebut menjadikan anak cepat bosan dan anak kurang berminat untuk belajar sehingga kegiatan pembelajarannya berpusat pada guru.(Maulidiah, 2016). Kemudian penelitian yang dilakukan oleh Leli Fertiliana Dea dan Eva La Tipah terjadi permasalahan bahwa guru belum mampu merencanakan dan menyiapkan media pemblajaran yang akan digunakan dalam kelas. (Dea, 2017). Selanjutnya penelitian serupa juga dilakukak oleh Muhammad Busyro Karim dan Siti Herlina Wifroh yang menyatakan bahwa guru jarang memanfaatkan fungsi media.(Wifroh, 2014).

Berdasarkan hasil pra seurvey menghasilkan tentang rendahnya kemampuan peserta didik hal itu menunjukkan kelemahan dalam belajar yang dlam hal ini bebrrti kelemahan dalam memahami konsep dasar dalam bermain. Hal ini disebabkan karena pemainan yang monoton sehingga berakibat perkembangan kognitif anak menjadi rendah. Banyak siswa yang beranggapan bahwa bermain dengan menggunakan media merupakan permainan yang sangat sulit dan tidak disukai. Sejalan dengan kenyataan yang ada bahwa selama ini alat permainan yang di miliki sekolah sangat terbatas dan minim. Supaya pembelajaran yang disampaikan oleh guru kepada anak didik lebih mudah diterima maka perlunya tindakan tertentu yang dirasa perlu untuk meningkatkan perkembangan kognitif anak usia dini. Tindakan yang dilakukan adalah dengan menggunakan metode yang tepat dalam pemblajaran anak usia dini.

Karekteristik belajar anak berbeda dengan orang dewasa, moeslihatoen menjelaskan bahwa cara belajar anak adalah dengan bermain seraya belajar, namun hal tersebut harus dengan kekondusifan dan keaktifan anak, penyajian materinyapun harus dikemas semenarik dan informatif sehingga anak dapat berlatih dan belajar dalam suasana yang menyenangkan tanpa meninggalkan tujuan pembelajaran tersebut. (Moeslichatoen, 2012, p. 24). Linda dalam Anita Yus berpendapat bahawa bermain merupakan peluang bagi anak untuk mendapatkan informasi dan melalukan banyak hal yang disenangi. Dari situasi itulah anak belajar tetang objek, kejadian, situasi dan sebuah konsep.(Yus, 2011, p. 33). Piaget dalam santrock mengungkapkan bahwa 
bermain adalah proses kegiatan yang dilakukan anak secara berulang untu mencapai kesenanangan dan kepuaan bagi dirinya.(Santrock, 2002, p. 212).

Dalam buku yang sama yang dikutip oleh Anita Yus, Schiller dan Spencer mengatakan bahwa bermin merupakan wahana untuk mengekspresikan sesuati sehingga terlepas dari tekanan. Selain itu juga bermain dapat membantu anak mengenal dirinya sendiri, dengan siapa dia hidup dan dimana lingkungan dia hidup. Melalui kegiatan bermain anak dapat mengendalikan diri sendiri, memahami kehidupan dan memahai dunia sehingga bermaian merupakan cerminan bagi perkembangan anak. Pengaruh dalam bermain ini salah satunya untuk meningkatkan perkembangan kognitif anak. (Yus, 2011, p. 35). Salah satu metode bermain untuk meningkatkan perkembangan kognitif anak adalah bermain peran (role playing). Jean piaget menyatakan bahwa perkembangan brmain anak salah satunya adalah simbolik make-believe play yaitu terjadi pada usia 2-7 tahun permainan tersebut ditandai dengan bermain pura-pura. Anak mulai banyak bertanya dalam kegiatan bermainnya. Mencoba berbagai hal yang belum prnah di dapat sebelumnya tentang konsep ruang, angkah, kuantitas dan sebagainya. (Piaget, 2010, p. 67).

Novan Ardy Wiyani berpendapat bahwa dalam bermain simbolik akan memberikan kontribusi dalam mengoptimalisasikan perkembangan kognitif pada anak usia dini, hal itu disebabkan karena dalam kegiatan bermain kognitif anak secara bergantian akan terjadi asimilasi an akomodasi. Kegiatan bermain simbolik akan dikembangkan anak untuk berfikir abstrak dan kemungkinan pura-pura, serta mempelajrai kata-kata maupun ungkapan baru yang besumber dari peran yang dimainkan oleh anak dalam situasi serba baru(Wiyani, 2014, p. 91). Menurut Rini Hildayani, dkk yang dikutip oleh Novan Ardy Wiyani mengartikan bahwa bermain simbolik dilakukan dengan dasar kemampuan untuk mempresentasikan pengalaman yang aktual atau khayalnya. Dengan penggunaan berbagai bahasa, gerakan dan objek. Sebagai contoh dalam kegiatan bermain masak-masakan, dokter-dokteran, polisi polisian dan bermain kemah-kemahan dan lain sebagainya.(Wiyani, 2014, p. 91)

Berdasarkan pendajabaran diatas apat dsimoulkan bahwa bermin peran (role playing) adalah sah satu metode yang digunakan untuk meningkatkan pekembangan berbagai aspek usia dini salah satunya adalah perkembangan kognitif. Hal tersebut dikarenakan kegitan bermain simbolik merupakan kegiatan permainan yang dapat memberikan kontribusi dalam mengoptimalisasikan perkembangan kognitif pada anak usia dini sbab bermiannyapun secara bergantian. Kegiatan bermain simbolik dikembangkan untuk kemampuan berfikir anak dan memungkinkan untuk berpura-pura, serta mempelajari kata atau ungkapan baru yang bersumber dari situasi dan kondisi serba baru.

\section{METODE}

Penelitian ini menggunakan jenis peneitian deskriptif kulitatif. Penelitin ini berusaha untuk mendeskripsikan gelaja, peristiwa, kejadian yang terjadi sekarang dimana penelitian ini akan memotret kejadian yang akan menjadi fokus penelitian kemudian akan dijabarkan sebagaimana adanya.(Bungin, 2011, p. 37). Lokasi dalam penelitian ini di Raudhatul Athfal Az-Zahra Natar Lampung Selatan. Subjek dalam penelitian ii dalah kepala sekolah, guru dan pesera didik atau siswa kelas B1.

Pelaksanaan dalam penelitian ini pada semester genap yang memasuki tahun pelajaran 2018/2019. Dalam mengumpulkan data penulis menggunakan wawancara, 
observasi dan dokumentasi. Observasi dilakukan dengan observasi partisipan dan non partisipan.(Yin, 2012, p. 27). Observasi partisipan adalah observasi yang dilaksanakan dengan cara mengikuti langsung objek yang menjadi fokus penelitian yang dalam hal ini adalah mengikuti langsung pembelajaran yang ada di RA Athfal Az-Zahra Kecamatan Natar Kabupaten Lampung Selatan. Sedangkan observasi non partisipan adalah observasi yang dilaksanakan secara tidak langsung. Dalam penelitian ini observasi secara tidak langsung adalah tentang lingkungan yang digunakan dalam menerapkan metode bermain peran (role playing) dalam meningkatkan perkembangan kognitif di Raudhatul Athfal Az-Zahra Kecamatan Natar Kabupaten Lampung Selatan. Wawancara yang digunakan juga wawancara bebas terpimpin yang dilakukan kepada guru dan anak. Dokumentasi yang penulis dapatkan adalah rancangan kegiatan pembelajaran yaitu RPPH.

Instrument dalam penelitian ini adalah peneliti sendiri (key instrument). Instrumen tersbut berupa instrumen wawancara, dokumentasi dan observasi. Setelah pengumpulan data dan instrumen yang telah didapatkan maka hasil penelitian ini dianalisis menggunakan model analisis miles huberman diantaranya adalah reduksi data, penyajian data dan penarikan kesimpulan. Uji keabsahan dilakukan dengan teknik triangulasi dimana teknik ini adalah untuk mengecek kembali data yang sudah ada melalui triangulasi sumber, metode dan waktu.

\section{HASIL PENELITIAN DAN ANALISIS}

Penelitian deskriptif kualitatif ini adalah untuk mendeskripsikan temuan-temuan hasil penelitian. Dokumentasi adalah pendukung dalam melengkapi data yang di dapatkan sebagai sebuah pendukung untuk mempekuat hasil temuan penelitian pad saat wawancara dan observasi. Yang mana hasil wawancara,observasi dan dokumentasi tersebut telah penulis lakukan. Pelaksanaan dalam penelitian ini adalah di RA Az-Zahra Natar Lampung Selatan. Fokus sumber data dalam penelitian ini adalah anak usia 5-6 tahun dengan rasio 10 anak perempuan dan 10 anak laki dalam kelas B1.

Dalam mengembangkan kemampuan kognitif anak usia 5-6 tahun melalui metode bermain peran di RAAz-Zahra Natar Lampung Selatan ternyata menghasilkan pekembangan kognitif anak yang cukup optimal. Hasil tersebut didapatkan dalam wawancara, observasi yang sudah penulis analisis sebelum memberikan pernyataan bahwa pekembangan kognitif anak cukup baik. Metode pengumpulan data tersebut sesuai dengan fakta yang ada dilapangan dan apa adanya.

Awal mula penelitian ini penulis lakukan di RA Az-Zahra Natar Lampung Selatan adalah untuk mengamati penerapan metode bermain peran (role playing) dalam mengembangkan kognitif anak usia 5-6 tahun. Metode deskriptifyang digunakan dalam penelitian ini aalah pengambilan sebuah kesimpulan yang di dapat dari hasil observasi dalam kegiatan belajar anak, wawancara yang dilakukan kepada kepala sekolah, guru dan peserta didik serta temuan-temuan lainnya yaitu dokumentasi. Seteleah semua data terkumpul, maka temuan itu akan dianalisis yang bertolak pada fakta yang disimoulkan secara generalisasi. Penerapan metode bermain peran dalam mengenmabngkan kognitif anak usia 5-6 tahun adalah fokus penelitian yang dilakukan. Dibawah ini adalah tabel hasil penelitian yang didapatkan melalui wawancara, observasi dan dokumentasi.

Tabel 1. Data Hasil Penelitian Perkembangan Kognitif Anak Usia 5-6 Tahun Kelompok B1 Di Raudhatul Athfal Az-Zahra 


\begin{tabular}{|c|c|c|c|c|c|c|c|}
\hline \multirow[t]{2}{*}{ No. } & \multirow{2}{*}{ Nama Anak } & \multicolumn{5}{|c|}{ Indikator Pencapaian Perkembangan } & \multirow{2}{*}{ Ket } \\
\hline & & $\mathbf{A}$ & $\mathbf{B}$ & $\mathbf{C}$ & $\mathbf{D}$ & $\mathbf{E}$ & \\
\hline 1. & ANW & 3 & 3 & 3 & 3 & 4 & 3 \\
\hline 2. & $\mathrm{AH}$ & 3 & 3 & 3 & 4 & 4 & 3 \\
\hline 3. & $\mathrm{ADA}$ & 3 & 2 & 3 & 2 & 2 & 2 \\
\hline 4. & $\mathrm{BB}$ & 3 & 2 & 2 & 2 & 3 & 2 \\
\hline 5. & $\mathrm{CP}$ & 3 & 2 & 3 & 3 & 3 & 3 \\
\hline 6. & DDL & 3 & 3 & 4 & 4 & 3 & 4 \\
\hline 7. & EON & 3 & 2 & 2 & 2 & 3 & 2 \\
\hline 8. & FLN & 3 & 2 & 3 & 3 & 3 & 3 \\
\hline 9. & GAP & 3 & 2 & 3 & 2 & 2 & 2 \\
\hline 10. & KDAZ & 3 & 2 & 2 & 2 & 2 & 2 \\
\hline 11. & MA & 3 & 2 & 3 & 3 & 2 & 3 \\
\hline 12. & MAR & 3 & 3 & 3 & 3 & 2 & 3 \\
\hline 13. & $\mathrm{NJ}$ & 3 & 2 & 2 & 3 & 3 & 3 \\
\hline 14. & NDP & 3 & 2 & 3 & 2 & 2 & 3 \\
\hline 15. & NKC & 2 & 2 & 2 & 2 & 2 & 2 \\
\hline 16. & NMH & 2 & 2 & 2 & 2 & 2 & 2 \\
\hline 17. & NW & 3 & 2 & 3 & 2 & 2 & 2 \\
\hline 18. & RA & 4 & 2 & 3 & 3 & 2 & 3 \\
\hline 19. & RDS & 4 & 2 & 3 & 3 & 3 & 3 \\
\hline 20. & RSP & 4 & 2 & 3 & 3 & 3 & 3 \\
\hline
\end{tabular}

\section{Keterangan Indikator:}

A. Menyebutkan lambang bilangan 1-10

B. Menunjukkan sikap kreatif dalam menyelesaikan masalah (ide, gagasan, di luar kebiasaan)

C. Mengklasifikasikan benda berdasarkan warna, bentuk, dan ukuran (3 variasi)

D. Mengklasifikasikan benda yang lebih banyak ke dalam kelompok yang sama atau kelompok yang sejenis, atau kelompok berpasangan yang lebih dari 2 variasi

E. Mengurutkan benda berdasarkan ukuran dari paling kecil ke paling besar atau sebaliknya

\section{Keterangan Nilai}

1 : Belum Berkembang

2 : Mulai Berkembang

3 : Berkembang Sesuai Harapan

4 : Berkembang Sangat Baik

Data diatas dapat penulis deskripsikan bahwa dalam bermain peran guru menggunakan langkah-langkah sebagai jembtan untuk ketercapaian perkembangan kognitif dalam kegiatan bermaian yaitu: pemanasan (warming up), memilih pemain (partisipan), menata panggung, menyiapkan pengamat (observer), memainkan peran (manggung), diskusi dan evaluasi, memainkan peran ulang, diskusi dan evaluasi kedua, serta berbagi kesimpulan dan pengalaman. 
Dari indikator perkembangan anak diatas indikator yang pertama bahwa anak dapat menyebutkan lambang bilangan 1-10. Data yang dihasilkan bahwa terdapat 7 anak yang perkembang kognitifnya sudah berkembang sangat baik, hal tersebut terlihat pada saat anak memerankan sebagai seorang guru dan anak anak lainnya dapat menyebutkan angka 1-10, dan anak-anak menyebutkan ciri-ciri bentuk bilangannya. Ada 11 anak yang berkembang sesuai dengan harapan dan 2 anak masih dalam tahap mulai berkembang. Karena hal tersebut terliht dalam observasi. Indikator kedua yaitu anak dapat menunjukkan sikap kreatif dalam penyelesaian masalah. Indikator ini didapatkan bahwa terdapat 8 anak yang sudah menunjukkan perkembangan sangat baik hasil tersebut di dapat pada saat anak bermain semua berantakan dan terdapat beberapa anak saja yang membereskan mainannya, terdapat juga pada saat jam istirahat anak mengambil bekal sendiri tanpa bantuan dari guru atau temannya yang lain. Anak dapat mengklasifikasikan benda berdasarkan warna, bentuk dan ukuran terdapat pada indikator ketiga yang menghasilkan 9 anak berkembang sangat baik dimana hal tesebut dilihat pada saat bermain peran bertemakan profesi yaitu pedagang dan pembeli. Hal itu terlihat pada saat anak memisahkan antara ukuran, warna dan bentuk yang akan dijualnya. Ada 1 anak berkembang sangat baik dan 13 anak berkembang sesuai harapandan 6 diantaranya mulai berkembang. Indikator selanjutnya adalah anak dapat mengklasifikasikan benda kedalam kelompok yang sama dan sejenis secara berpasangan yang lebih dari 2 variasi. Dalam indikator tersebut di dapatkan 2 anak berkembang sangat baik dan 9 anak sudah berkembang sesuai harapan. Terdapat 2 anak berkembang sangat t baik dan 8 anak berkembang sesuai dengan harapan sert 10 ank mulai berkembang data tersebut ada pada indikator terakhir yaitu anak dapat mengurutkan benda berdasarkan ukuran terkecil ke terbesar dan terbesar ke terkecil.

Data dan deskripsi diatas menunjukkan hasil penelitin pada penerapan kegiatan bermain peran untuk perkembangan kognitif anak usia 5-6 tahun. Adapun langkahlangkah yang digunakan dalam menerapkan bermain peran yaitu: Melalui pemanasan, dalam langkah pemanasan guru memperkenalkan anak pada suatu kejadian, kemudian guru menggambarkan dengan jelas. Pemanasan dilakukan agar anak siap dan mengetahui apa yang akan dilakukan. Dalam menggambarkan permasalahan guru sudah cukup jelas menyampaikan dan memberikan contoh.

Guru menggambarkan permasalahan yang jelas yang disertai dengan contoh. Memilih pemain (partisipan) dalam langkah ini anak dan guru akan membahasa karakter dari pemain yang akan diperankan dan siapa yang akan memerankannya. Dalam pemilihan pemainan ini guru akan memilih anak yang sesuai dengan karakter yang akan dimainkan. Dalam langkah tersebut terdapat kegiatan perdagangan yaitu adanya penjual dan pembeli. Guru akan memilih anak yang akan menjadi penjual dan anak yang akan menjadi pembeli. Langkah selanjutnya adalah menata panggung, dalam hal ini menata panggung adalah guru mendiskusikan dengan anak dimana dan bagimana peran yang akan dimainkan.penataan panggung ini dapat dibuat sederhana dan kompleks. yang paling sederhana adalah membahas tentang skenario (tanpa dialog lengkap) yang akan menggambarkan urutan pemainan peran. Kemudian langkah selanjutnya adalah menyediakan pengamat, dalam hal ini guru akan menunjuk pengamat yang terdiri dari salah satu anak. Kriteria pemilihan pengamat harus anak yang aktif faham memainkan perannya. memainkan peran (manggung) permainan peran dilaksanakan secara spontan.

Pada awalnya akan banyak siswa yang masih bingung memainkan perannya atau bahkan tidak sesuai dengan peran yang seharusnya ia lakukan. Bahkan, mungkin ada 
yang memainkan peran yang bukan peranannya. Jika permainan peran sudah terlalu jauh keluar jalur, guru dapat menghentikannya untuk segera masuk ke langkah berikutnya. Hal ini dilakukan agar melatih anak dalam berpikir simbolik dan mengekspresikan perasaannya melalui peran yang dimainkannya. Selanjutnya adalah diskusi dan evaluasi yang dilakukan guru bersama anak-anak yakni mendiskusikan permainan yang telah dilakukan dan melakukan evaluasi terhadap peran-peran yang telah dilakukan. Hal ini akan menghasilkan usulan perbaikan. Setelah melakukan evaluasi kemudian memainkan peran ulang (manggung ulang) seharusnya, pada permainan peran kedua ini akan berjalan lebih baik, siswa dapat memainkan perannya lebih sesuai dengan skenario. Selanjutnya adalah diskusi dan evaluasi lebih diarahkan pada realitas. Mengapa demikian? Karena pada saat permainan peran dilakukan, banyak peran yang melampaui batas kenyataan. Misalnya seorang anak memainkan peran sebagai pembeli. Ia membeli barang dengan harga yang tidak realitas. Hal ini dapat menjadi bahan diskusi. Dan yang terakhir berbagi Kesimpulan dan Pengalaman adalah siswa diajak untuk berbagi pengalaman tentang tema permainan peran yang telah dilakukan dan dilanjutkan dengan membuat kesimpulan. Misalnya anak akan berbagi pengalaman tentang bagaimana cara menabung di bank. Kemudian guru membahas bagaimana tahap-tahap ketika kita ingin menabung di bank.

Berdasarkan data penelitian dan anaisis diatas dapat disimpulkan bahwa guru berusaha semaksimal mungkin dalam menerapkan kegiatan bermain peran dalam mengembangkan kognitif anak usia 5-6 tahun. Dan dalam langkah-langkah penerapan bermain peran telah menunjukkan hasil yang maksimal.

\section{PEMBAHASAN}

Data deskripsi dari hasil observasi, wawancara dan dokumentasi diatas. Dapat disimpulkan bahwa guru telah memberikan kegiatan dalam mengembangkan kognitif anak melalui interaksinya kepada anak. Pendidik menggunakan metode bermain peran dalam pembelajaran, agar anak tertarik dan pembelajaran menjadi menyenangkan. Karena pada hakekatnya pembelajaran yang sesuai dengan anak adalah pembelajaran yang di desain secara menyenaangkan yaitu belajar sambil bermain. Dalam Kegiatan Pembelajarannya RA Az-Zahra Natar menggunakan beragai metode yang salah satunya adalah metode bermain peran. Metode bermain peran yang di terapkan di RA tersebut masih terbatas hal tersebut dikarenakan media yang minim. Namun hal tersebut tidak menjadi hambatan bagi guru dalam melaksanakan kegiatan bermain peran. Hal tersebut sejalan dengan Muktar Latief yang berpendapat bahwa metode bermain peran adalah cara belajar agar untuk menuangkan segala pengetahuan dan sebuah rasa kedalam peran .(Latief, 2013, p. 130)

Pada perkembangan kognitif anak usia 5-6 tahun anak mulai berfikir secara simbolik. Hal ini sejalan dengan metode yang digunakan yaitu bermain peran. Jean piaget berpendapat bahwa bermain salah satunya bermain simbolik terjadi pada anak usia 2-7 tahun yang ditandai dengan khayalan atau pura-pura. Pada umur 5-6 tahun anak banayak bertanya ketia dalam kegiatan bermainnya, anak mencoba mnanyakan hal-hal yang baru kepada pendidik yang berkaitan dengan konsep ruang angka, kuantitas dan sebagainya. (Piaget, 2010, p. 67). Sependapat dengan piaget warsiyah juga mengungkapkan bahwa bermain peran anak mampu mengenali sebuah konsep secara sederhana, seperti ketika latihan menulis angka sebagai latihan untuk mengasah motorik halus dn anak dapat menyebutkan angka 1-5 dan menjawab pertanyaan yang diberikan oleh guru. (Warsiyah, 2014, p. 56). 
Mulyasa mengatakan bahwa hakikat dalam bermain peran dalam pendidikan anak usia dini adalah keterlibatan emosi dan pengamat tentang situasi dan kondisi masalah yang dihadapi oleh anak secara nyata.(Mulyasa, 2008, p. 89). Dalam hal ini anak mampu mengeksplorasi perasaan sehingga memperoleh wawasan tentang bagimana bersikap, nilai yang ada pada masyarakat dan persepsinya serta bagimana anak memecahkan suatu permasalahan yang sedang dihadapi. Keberhasilan suatu metode tergantung pada kualitas dan cara yang diberikan oleh pendidik. Keberhasilan metode bermain peran dalam pembelajaran itu tergantung pada kualitas permainan perannya. Yaitu tentang bagaimana individu memainkan peran yang sedang ia lakoni di dunia nyata.(Uno, 2012, p. 31)

Berdasarkan pembahasan diatas tentang evaluasi metode bermain peran dalam mengembangkan kognitif anak disimpulkan bahwa pada perkembangan kognitif anak di RA Az- Zahra Natar telah cukup berkembang hari demi hari karena proses pembelajarannya yang tidak monoton. Melainkan belajar sambil bermain yang salah satunya adalah bermain simbolik dengan metode bermain peran. Karena metode bermain peran merupakan metode yang digunakan untuk memainkan sebuah tokohtokoh atau benda yang berada di sekitar anak agar anak dapat mengembangkan daya imajinasi serta penghayatan terhadap kegiatan yang tengah dilaksanakan melalui permainan peran tersebut. Dalam kegiatan ini anak diharapkan mampu untuk mengeksplorasi rasa penasarannya, lebih mengembangkan persepsinya, mengembangkan sikap dan keterampilan serta dapat mengeksplorasi tentang permasalahan yang tengah diperankan.

\section{SIMPULAN DAN SARAN}

Pemaparan diatas merupakan analisis dan pembahasan serta hasil penelitian yang diperoleh. Maka dari gambaran diatas dapat penulis simpulkan bahwa dalam penerapan metode bermain peran dalam megenangkan kognitif anak di RA Az- Zahra Natar Lampung Selatan sudah berjalan baik dan menghasilkan perkembangan kognitif yang baik. Perkembangan kognitif anak di RA Az- Zahra Natar telah berkembang secara optimal. Meskipun medianya trbatas namun hal tersbut tidak menjadi suatu hambatan pendidik dalam melakukan metode bermain peran. Kegiatan metode bermain peran dikemas pendidik dengan mempertimbangkan media yang ada, namun hal itu sangat luar biasa. dalam penerapan metode bermain terdapat langkah-langkah yang harus dilalui mulai dari pemanasan (warming up), memilih pemain (partisipan), menata panggung, menyiapkan pengamat (observer), memainkan peran (manggung), diskusi dan evaluasi, memainkan peran ulang (manggung ulang), diskusi dan evaluasi kedua dan berbagi kesimpulan sampai berbagi pengalaman.

Dengan melihat data yang telah didapatkan kemudian dianalisis maka penulis menyarankan bahwa metode bermain peran sangat cocok diterapkan di lembaga pendidikan anak usia dini. Karena metode bermain peran ini sangat menyenangkan dan pembelajaran anakpun menjadi bermakna. Dan sebelum melakukan kegiatan bermain peran guru hendaknya menyiapkan media yang sangat mendukung dalam kegiatan pembelajaran tersebut agar mendapat hasil yang masksimal.

\section{AKNOWLEDGMENT}

Peneleitian ini di dukung oleh UIN Sunan Kalijaga Yogyakarta dan UIN Raden Intan Lampung. 


\section{DAFTAR RUJUKAN}

Anwar, C. (2014). Hakikat Manusia dalam Pendidikan sebuah Tinjauan Filosofis. Yogyakarta: Suka Press.

Bungin, B. (2011). Penelitian Kualitatif. Komunikasi, Ekonomi, Kebijakan Publik, Dan Ilmu Sosial Lainnya. Jakarta: Kencana.

Dea, E. L. T. dan L. F. D. E. L. T. dan L. F. (2017). Pengembangan Kemampuan Kognitif Dan Sosial-Emosional Melalui Penerapan Media Balok Dan Bermain Peran Pada Siswa Tk Kuntum Mekar, Lampung. Al-Athfal Jurnal Pendidikan Anak, 3(2).

Eleanor Sautelle, Terry Bowles, John Hattie, D. N. A. (2015). Personality, Resilience, Self-Regulation and Cognitive Ability Relevant to Teacher Selection. Australian Journal of Teacher Education, 40(4), 53-71.

Latief, M. (2013). Orientasi Baru Penidikan Anak Usia Dini Teori dan Aplikasi. Jakarta: Prenada media Group.

Maulidiah, D. (2016). Peningkatan Perkembangan Kognitif Melalui Pembelajaran Sains Dengan Metode Proyek Di Taman Kanak-Kanak. UNTAN.

Moeslichatoen. (2012). Metode Pengajaran di Taman Kanak-Kanak. Jakarta: Rineka Cipta.

Mulyasa, E. (2008). Menjadi Guru yang Profesional (Menciptakan Pembelajaran yang Kreatif dan Menyenangkan). Bandung: Rosdakarya.

Piaget, J. (2010). Psikologi Anak (The Psychology of the Child). In M. Jannah (Ed.), The Psychology of the Child. Yogyakarta: Pustaka Pelajar.

Salmiati, Nurbaity, dan D. M. S. (2016). Upaya Guru dalam Membimbing Perkembangan Kognitif Anak Usia Dini” (Suatu Penelitian di Taman KanakKanak Islam Terpadu Ar-Rahmah, Kota Banda Aceh). ISSN 2355-120X, 3(1).

Santrock, J. W. (2002). Life-Span Developent Jilid 1 (Alih Bahasa: Achmad Chusairi). Jakarta: Erlangga.

Uno, H. B. (2012). Model Pembeljarn Menciptakan Proses Belajar Mengajar yang Kreatif dan Efektif. Jakarta: Bumi Aksara.

Warsiyah. (2014). Upaya Meningkatkan Kemampuan Kognitif Anak Melalui Bermain Peran Pada Kelompok B Tk Aba Jimbung Iv Kecamatan Kalikotes Tahun Ajaran 2012 / 2013. FKIP PAUD, 1(5).

Wifroh, M. B. K. dan S. H. (2014). Meningkatkan Perkembangan Kognitif melalui Alat Permainan Edukatif. Jurnal PGPAUD Universitas Trunojoyo Madura, 1(2).

Wiwien, P. i D. (2008). Psilogi Anak Usia Dini. Jakarta: Indeks.

Wiyani, N. A. (2014). Psikologi Perkembangan Anak Usia Dini. Yogyakarta: Gava Media.

Yin, R. K. (2012). Studi Kasus Desain dan Metode. Jakarta: Grafindo Persada.

Yus, A. (2011). Penilaian Perkembangan Belajar Anak Taman Kanak-Kanak. Jakarta: Kencana. 


\section{AUTHOR}

Wardah Anggraini, dilahirkan di Pringsewu pada tanggal 24 Agustus 1996. Penulis merupakan anak pertama dari empat bersaudara. Penulis merupakan lulusan dari Fakultas Ilmu Tarbiyah dan Keguruan Program Studi Pendidikan Islam Anak Usia Dini yang lulus pada tahun 2018. Pada tahun yang sama penulis melanjutkan pendidikan program magister di Fakultas Ilmu Tarbiyah dan Keguruan Program Studi Pendidikan Islam Anak Usia Dini UIN Sunan Kalijaga Yogyakarta. Penulis saat ini masih menjadi mahasiswa aktif yang sedang menyelesaikan tugas akhir (tesis).

Anggi Darma Putri, anak kedua dari dua bersaudara yang dilahirkan di Natar, 08 November 1995. Penulis juga merupakan lulusan dari Fakultas Ilmu Tarbiyah dan Keguruan Program Studi Pendidikan Islam Anak Usia Dini yang lulus pada tahun 2018. Saat ini penulis mengajar di RA Al-Asyrof Natar Lampung Selatan. 